\title{
BASIC PROPERTIES IN RELATION TO DRYING PROPERTIES OF THREE WOOD SPECIES FROM INDONESIA
}

\author{
Efrida Basri ${ }^{1}$, Nurwati Hadjib ${ }^{1}$ and Saefudin ${ }^{2}$
}

\begin{abstract}
The objectives of this study were to investigate basic and drying properties of three wood species from Indonesia, i.e. kuda (Lannea coromandelica Merr.), waru (Hibiscus tiliaceus L. and mindi besar (Melia dubia Cav.). The basic properties include density, shrinkages, modulus of rupture (MOR), compression parallel to grain $(\mathrm{C} / /)$, wood strength and anatomical structures. Meanwhile, the drying properties included drying time and drying defects. The initial-final temperature and humidity for each species was based on defects that resulted from high temperature drying trial.

The results showed that the drying properties were significantly affected by wood anatomical structure. The initial-final drybulb temperature and wetbulb depression for kuda wood are $50-70^{\circ} \mathrm{C}$ and $3-30^{\circ} \mathrm{C}$ respectively, while the corresponding figures for waru wood are $65-80^{\circ} \mathrm{C}$ and $6-30^{\circ} \mathrm{C}$, and for mindi besar wood are $55-80^{\circ} \mathrm{C}$ and $4-30^{\circ} \mathrm{C}$. These drying schedules, however, still need further trial prior to their implementation in the factory-scale operation. All wood species studied have density and considerable strength recommended in their use for light medium construction purposes. Mindi besar wood has decorative appearance so it is suitable for furniture.
\end{abstract}

Keywords: basic properties, drying properties, construction, furniture

\section{INTRODUCTION}

Indonesian wood industry is currently facing a shortage of raw material in the neighbourhood of 26 million cubic meter per annum (Departemen Kehutanan, 2003). One solution of this problem is utilizing some lesser-known timber species. However, lack of information on proper uses and the processing characteristics of these species limits their further utilization.

Drying process is a necessary step in processing wood. This process could improve wood dimension stability, surface color, resistance to fungi or powder post beetle and workability. However, the evaporation of water molecules from wood until wood reaches the desired moisture content is often followed by physical changes such as casehardening, checking, and/or warping. These changes are affected by some internal factors of the wood such as its anatomical structure (Panshin and de Zeuw, 1969; Skaar, 1988; Basri and Hadjib, 2004), and percentage of early-wood (Senft et al. 1986; Gerard et al., 1995 in Wahyudi, 2000), and density (Rasmussen, 1961). Knowledge on these factors is important in determining the proper drying schedule and further use of any specific wood species. The knowledge would also help reducing drying defect and time.

This study aimed to investigate the basic properties, i.e. Shrinkage, modulus of rupture (MOR), compression parallel to grain $(\mathrm{C} / /)$, and anatomical structures in relation to drying properties of three wood species from Indonesia, i.e kuda (Lannea coromandelica Merr.), waru (Hibiscus tiliaceus L), and mindi besar (Melia dubia Cav.). The basic properties will be used as the base

${ }^{1}$ Forest Products Technology Research and Development Center, Bogor 
in determining optimum drying schedule and proper use of those woods.

\section{MATERIALS AND METHODOLOGY}

Three wood species investigated were showed in Figure 1.

\section{A. Basic Properties Test}

Physical and mechanical properties studied in this experiment were density, shrinkage, modulus of rupture (MOR) and compression parallel to grain (C//). Sampling and testing procedure for physical and mechanical tests followed ASTM D143-94 (Anonim, 1995). The samples dimension were $3 \mathrm{~cm}$ by $3 \mathrm{~cm}$ by $3 \mathrm{~cm}$ for density and shrinkage tests, $3 \mathrm{~cm}$ by $3 \mathrm{~cm}$ by 42 $\mathrm{cm}$ for MOR test, and $3 \mathrm{~cm}$ by $3 \mathrm{~cm}$ by $12 \mathrm{~cm}$ for $\mathrm{C} / /$ test. Data on anatomical structure of these wood were taken from secondary data (Mandang and Artistien, 2003).

\section{B. Drying Properties}

Experiment on drying properties was carried out using quick drying test method. This method was established by Terazawa (1965). The procedures were as follows:

a. Several flat sawn-pieces measuring $2 \mathrm{~cm}(\mathrm{~T})$ by $10 \mathrm{~cm}$ (W) by $20 \mathrm{~cm}(\mathrm{~L})$ were measured of their initial weights and then oven-dried at $100^{\circ} \mathrm{C}$ until their moisture content reached approximately 1 percent.

b. Changes of moisture content and development of drying defects were observed i.e. initial checks, deformation, and honeycomb. The criterion in assessing these three kinds of defects were sizes and number of defects taking place on the surface of the dried lumber and were decided by the scaled values which ranged from 1 to 8 for initial checks as well as deformation, and from 1 to 6 for honeycomb. The lower the values the less the defects, while the higher the values the more severe the defects. Afterwards, the drying conditions, i.e. initial and final temperatures as well as initial wetbulb depression were estimated for 1 inch thick timber (Table 1).

c. Based on initial-final temperature and initial wetbulb depression values, the basic drying schedule for certain wood species were determined as described in the manual of Forest Products Laboratory, Madison (Terazawa, 1965). 


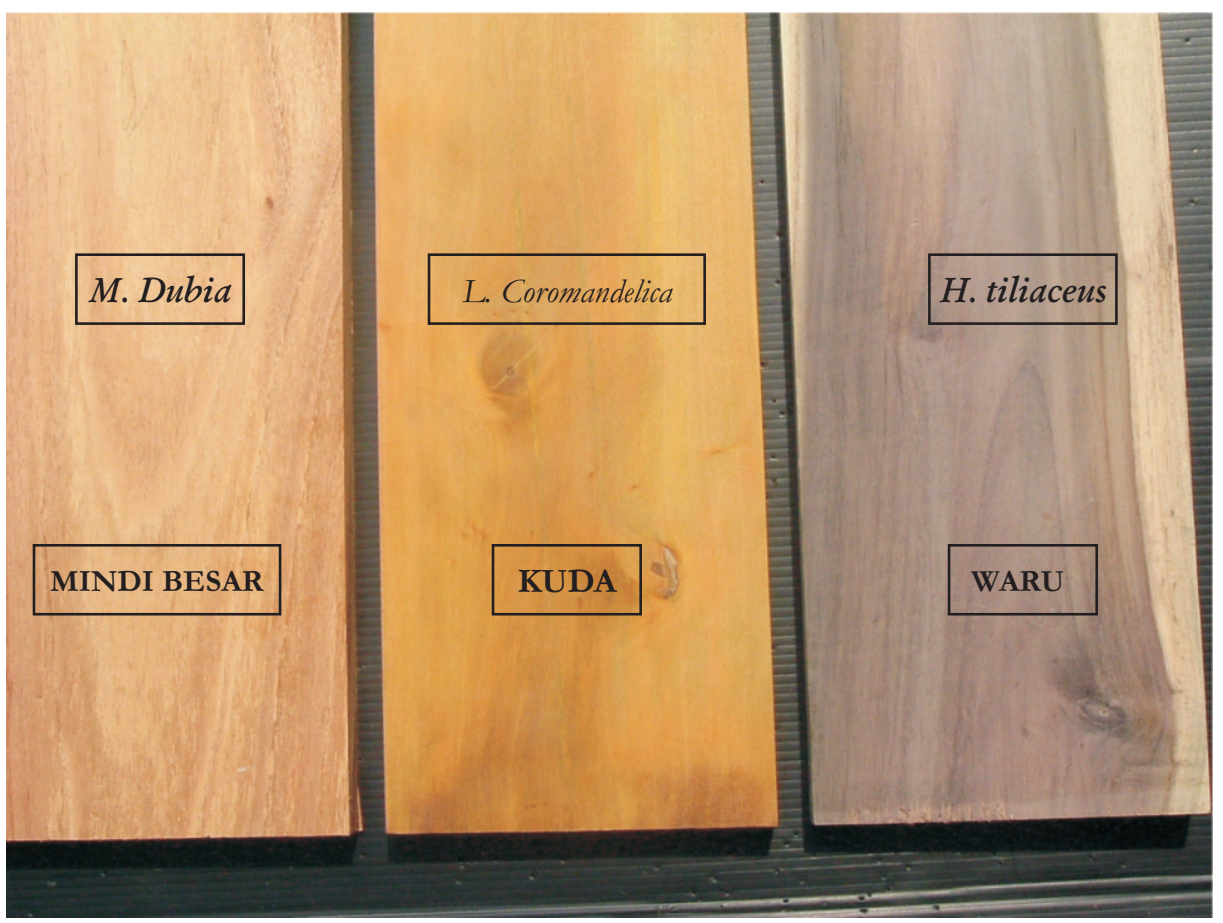

Figure 1. Three wood species investigated

Table 1. Degrees of each defect from standpoint of drying condition

\begin{tabular}{|c|c|c|c|c|c|c|c|c|c|}
\hline \multirow{2}{*}{ Variety of defect } & \multirow{2}{*}{ Drying condition } & \multicolumn{8}{|c|}{ Defect degrees } \\
\hline & & 1 & 2 & 3 & 4 & 5 & 6 & 7 & 8 \\
\hline \multirow[t]{3}{*}{ I. Surface check } & Initial temp., ${ }^{\circ} \mathrm{C}$ & 70 & 65 & 60 & 55 & 53 & 50 & 47 & 45 \\
\hline & WB depression & 6.5 & 5.5 & 4.3 & 3.6 & 3.0 & 2.3 & 2.0 & 1.8 \\
\hline & Final temp., ${ }^{\circ} \mathrm{C}$ & 95 & 90 & 85 & 80 & 80 & 80 & 80 & 80 \\
\hline \multirow[t]{3}{*}{ II. Deformation } & Initial temp., ${ }^{\circ} \mathrm{C}$ & 70 & 66 & 58 & 54 & 50 & 49 & 48 & 47 \\
\hline & WB depression & 6.5 & 6.0 & 4.7 & 4.0 & 3.6 & 3.3 & 2.8 & 2.5 \\
\hline & Final temp., ${ }^{\circ} \mathrm{C}$ & 95 & 88 & 83 & 80 & 77 & 75 & 73 & 70 \\
\hline \multirow[t]{3}{*}{ III. Honeycomb } & Initial temp., ${ }^{\circ} \mathrm{C}$ & 70 & 55 & 50 & 49 & 48 & 45 & - & - \\
\hline & WB depression & 6.5 & 4.5 & 3.8 & 3.3 & 3.0 & 2.5 & - & - \\
\hline & Final temp., $\quad{ }^{\circ} \mathrm{C}$ & 95 & 83 & 77 & 73 & 71 & 70 & - & - \\
\hline
\end{tabular}

Source: Terazawa (1965) 


\section{RESULT AND DISCUSSION}

\section{A. Wood Basic Properties}

Table 2 provided data on density and shrinkage, whereas Table 3 presented data on modulus of rupture (MOR) and compression parallel to grain $(\mathrm{C} / /)$. Dimension stability of each wood was shown by the ratio of tangential to radial shrinkage (T/R). Of the three species, Kuda wood has the highest $\mathrm{T} / \mathrm{R}$ ratio $(>3)$, whereas Mindi besar has $\mathrm{T} / \mathrm{R}$ ratio a little bit above $2 . \mathrm{T} / \mathrm{R}$ value that exceeds 2 indicates that the wood has less dimension stability and needs to be dried carefully.

\section{B. Drying Properties}

Table 2. Mean density and shrinkage of wood samples

\begin{tabular}{|c|c|c|c|c|c|c|c|}
\hline \multirow{3}{*}{ Wood species } & \multirow{3}{*}{$\begin{array}{l}\text { Air dry } \\
\text { density }^{1} \\
\mathrm{~g} / \mathrm{cm}^{3}\end{array}$} & \multirow{3}{*}{$\begin{array}{c}\text { Basic } \\
\text { density }^{2}, \\
\mathrm{~g} / \mathrm{cm}^{3}\end{array}$} & \multicolumn{4}{|c|}{ Shrinkage, $\%$} & \multirow{3}{*}{$\begin{array}{l}\mathrm{T} / \mathrm{R} \\
\text { ratio }\end{array}$} \\
\hline & & & \multicolumn{2}{|c|}{$\mathrm{G}-\mathrm{AD}^{3}$} & \multicolumn{2}{|c|}{ G-OD ${ }^{4}$} & \\
\hline & & & $\mathrm{R}$ & $\mathrm{T}$ & $\mathrm{R}$ & $\mathrm{T}$ & \\
\hline 1. Kuda & 0.50 & 0.45 & 0.59 & 1.77 & 2.82 & 6.75 & 3.2 \\
\hline 2. Waru & 0.54 & 0.50 & 0.80 & 1.62 & 3.03 & 6.10 & 2.0 \\
\hline 3. Mindi besar & 0.52 & 0.48 & 0.68 & 1.50 & 3.12 & 6.92 & 2.2 \\
\hline
\end{tabular}

Remarks: ${ }^{1)}$ Based on air dry weight and volume; ${ }^{2)}$ Based on oven dry weight and volume; ${ }^{3)}$ Green to air dry,

${ }^{2)}$ Green to oven dry; $\mathrm{R}=$ radial; $\mathrm{T}=$ tangential shrinkage

Table 3. Mean value of modulus of rupture (MOR), compression parallel to grain $(\mathrm{C} / /)$ and strength class of wood species tested

\begin{tabular}{|l|c|c|c|c|c|}
\hline \multicolumn{1}{|c|}{ Wood species } & $\begin{array}{c}\text { Air dry } \\
\text { density }\end{array}$ & $\begin{array}{c}\text { MOR } \\
\left(\mathrm{kg} / \mathrm{cm}^{2}\right)\end{array}$ & $\mathrm{S} / \mathrm{W}^{2)}$ & $\begin{array}{c}\mathrm{C} / / \\
\left(\mathrm{kg} / \mathrm{cm}^{2}\right)\end{array}$ & $\begin{array}{c}\text { Strength } \\
\text { class }^{3}\end{array}$ \\
\hline 1. Kuda & 0.50 & 279.979 & 559.96 & 218.272 & IV - III \\
2 Waru & 0.54 & 430.844 & 797.86 & 330.172 & III - II \\
3. Mindi besar & 0.52 & 440.480 & 847.08 & 332.105 & III - II \\
\hline
\end{tabular}

Remark: ${ }^{1)}$ Based on air dry weight and volume ${ }^{2)}$ Strength (S) to weight (W) ratio ${ }^{3)}$ Based on Indonesian wood strength classification (Oey, 1990)

Based on data presented in Table 2, and under Indonesian wood strength classification waru and mindi besar were classified into strength class III-II (Oey, 1990), while kuda wood was classified into strength class IV-III. Based on their general characteristics, strength class, and density, those three species could be used as light construction wood. Furthermore, mindi besar was recommended to be used as furniture wood due to its decorative appearance and good machining properties (Rachman, 2002). Wood suitable for furniture should have medium strength, decorative appearance, and good in machining (Ministry of Agriculture, 1976). On the other hand, waru wood is much more suitable for children toys or wooden-boat frame because of its relatively short clear bole. Through a proper drying process, the quality of three species could be improved. 
Green moisture content of the three species varies from one to others. Average moisture content were $84 \%$ for kuda wood, $60 \%$ for waru and $64 \%$ for mindi wood.

Tables 2 and 4 indicate that initial check, rather than honeycomb defect, depends on shrinkage degree. Surface checks occurred from the early drying process and reach the maximum degree at fiber saturation point. Therefore, the increasing of drying temperature is suggested to be done after the moisture content of wood reaches fiber saturation point condition.

The drying properties of each of three wood species are not affected by their densities but by their tangential to radial shrinkage ratio. Though their densities are almost similar one to another, their response to high temperature is different. The higher their ratio of tangential to radial shrinkage, the lower their dimension stability.

The anatomical structure of the wood apparently affects the evaporation of water from the wood (Panshin and de Zeuw, 1969). Some of those anatomical features were vessel, fiber wall, parenchyma and ray cells. Vessels containing no tyloses or amorf crystallites are important pathways for water evaporation during drying process. The bigger the diameter of the vessels, the easier the wood to dry. Ray cells could become an important barrier factor during drying process. The difference in their width could affect the ratio of tangential-to-radial shrinkage.

Mandang and Artistien (2003) reported that the vascular pore of kuda wood was the smallest among the three wood species. There are also tyloses in kuda vessels and silica in its ray cells. These affect the evaporation of water molecules from its radial and tangential surfaces, causing the wood easily to warp and split/check during drying process (Table 4).

Of the three species, waru wood was relatively easy to dry without forming any defects. Its dimension stability was high, as shown by its T/R ratio that is equal to 2 . This is caused by its huge vascular pore and the inexistence of crystallites or tyloses inside the cells that can hamper the drying process. Those facts showed that there was a close relationship of wood properties, particularly its anatomical structure, with its drying properties. The estimated initial-final drying

Table 4. High temperature drying results of woods investigated

\begin{tabular}{|l|c|c|c|c|c|c|}
\hline \multirow{2}{*}{ Wood species } & \multirow{2}{*}{$\begin{array}{c}\text { Basic } \\
\text { density }\end{array}$} & \multirow{2}{*}{$\begin{array}{c}\text { Initial } \\
\text { moisture } \\
\text { content, \% }\end{array}$} & $\begin{array}{c}\text { Drying time } \\
100^{\circ} \mathrm{C} \text { test } \\
\text { (Hours) }\end{array}$ & \multicolumn{3}{|c|}{ Variety of defect } \\
\cline { 5 - 7 } & & 84 & 18 & 4 & 5 & 1 \\
1. Kuda & 0.45 & 60 & 20 & 1 & $1-2$ & 1 \\
2. Waru & 0.50 & 64 & 20 & 1 & 3 & 1 \\
3. Mindi besar & 0.48 & & & & & II \\
\hline
\end{tabular}

Remarks: ${ }^{1)}$ Based on oven dry weight and volume; I. Surface check; II. Deformation; III. Honeycomb

temperature and wetbulb depression for each species were presented in Table 5. 
Table 5. Initial-final temperature and wetbulb depression of three wood species investigated

\begin{tabular}{|c|c|c|c|c|c|}
\hline \multirow{2}{*}{ Wood species } & \multirow{2}{*}{$\begin{array}{c}\text { Basic } \\
\text { density }^{1)}\end{array}$} & \multirow{2}{*}{$\begin{array}{l}\text { Initial moisture } \\
\text { content, } \%\end{array}$} & \multicolumn{2}{|c|}{ Temperature, ${ }^{\circ} \mathrm{C}$} & \multirow{2}{*}{$\begin{array}{c}\text { Wetbulb } \\
\text { depression, }{ }^{\circ} \mathrm{C}\end{array}$} \\
\hline & & & Initial & Final & \\
\hline 1. Kuda & 0.45 & 84 & 50 & 77 & 3.6 \\
\hline 2. Waru & 0.50 & 60 & 66 & 88 & 6.0 \\
\hline 3. Mindi besar & 0.48 & 64 & 58 & 83 & 4.7 \\
\hline
\end{tabular}

Remarks: ${ }^{1)}$ Based on oven dry weight and volume

\section{Basic Drying Schedule}

The basic drying schedule of three wood species as investigated, are presented in Table 6 - 8 .

Table 6. Drying schedule for Waru wood

\begin{tabular}{|c|c|c|c|}
\hline $\begin{array}{c}\text { Moisture content, } \\
\%\end{array}$ & $\begin{array}{c}\text { Drybulb temperature, } \\
{ }^{\circ} \mathrm{C}\end{array}$ & $\begin{array}{c}\text { Wetbulb depression, } \\
{ }^{\circ} \mathrm{C}\end{array}$ & $\begin{array}{c}\text { Relative humidity, } \\
\%\end{array}$ \\
\hline $60-40$ & 65 & 6 & 74 \\
$40-35$ & 65 & 8 & 67 \\
$35-30$ & 65 & 12 & 54 \\
$30-25$ & 70 & 20 & 35 \\
$25-20$ & 70 & 25 & 25 \\
$\leq 20$ & 80 & 30 & 22 \\
\hline
\end{tabular}

Table 7. Drying schedule for mindi besar wood

\begin{tabular}{|c|c|c|c|}
\hline $\begin{array}{c}\text { Moisture content, } \\
\%\end{array}$ & $\begin{array}{c}\text { Drybulb temperature, } \\
{ }^{\circ} \mathrm{C}\end{array}$ & $\begin{array}{c}\text { Wetbulb depression, } \\
{ }^{2} \mathrm{C}\end{array}$ & $\begin{array}{c}\text { Relative humidity, } \\
\%\end{array}$ \\
\hline $60-40$ & 55 & 4 & 81 \\
$40-35$ & 55 & 6 & 72 \\
$35-30$ & 55 & 9 & 60 \\
$30-25$ & 60 & 15 & 43 \\
$25-20$ & 65 & 20 & 35 \\
$20-15$ & 70 & 25 & 25 \\
$\leq 15$ & 80 & 30 & 22 \\
\hline
\end{tabular}


Table 8. Drying schedule for kuda wood

\begin{tabular}{|c|c|c|c|}
\hline $\begin{array}{c}\text { Moisture content, } \\
\%\end{array}$ & $\begin{array}{c}\text { Drybulb temperature, } \\
{ }^{\circ} \mathrm{C}\end{array}$ & $\begin{array}{c}\text { Wetbulb depression, } \\
{ }^{\circ} \mathrm{C}\end{array}$ & $\begin{array}{c}\text { Relative humidity, } \\
\%\end{array}$ \\
\hline $80-50$ & 50 & 3 & 84 \\
$50-40$ & 50 & 4 & 80 \\
$40-35$ & 50 & 6 & 71 \\
$35-30$ & 50 & 10 & 54 \\
$30-25$ & 55 & 18 & 32 \\
$25-20$ & 60 & 24 & 22 \\
$20-15$ & 65 & 25 & 22 \\
$\leq 15$ & 70 & 30 & 17 \\
\hline
\end{tabular}

The hardest schedule at temperature range $65-80^{\circ} \mathrm{C}$ could only be used to dry Waru wood, whereas the mildest schedule at temperature range of $50-70{ }^{\circ} \mathrm{C}$ was used for kuda wood. In their implementation, each of the drying schedule needs to be modified and adjusted to kiln condition, initial moisture content and the dimension of wood to be dried. For instance, a $20 \mathrm{~cm}$-length mindi besar did not bow or cup when dried at high temperature. However, wood with longer dimension might bow as there are crystallites found inside the axial parenchyma cells of mindi besar that will affect the evaporation of water in the longitudinal direction of the wood.

\section{CONCLUSION AND RECCOMMENDATION}

1. Based on their physical, mechanical properties and decorative appearance of the three wood species, mindi besar is suitable for fancy furniture whereas waru is for children's toys or wooden-boat frames. Therefore, both species are recommended for utilization at industrial scale.

2. Based on the experiment at high drying temperature, initial and final drying temperature the wetbulb depression, for waru was $66-88^{\circ} \mathrm{C}$ and 6.0 ; for mindi was $58-83^{\circ} \mathrm{C}$ and 4.7 ; and for kuda was $50-77^{\circ} \mathrm{C}$.

3. Referring to the standard issued by Forest Products Laboratory Madison, the initialfinal drybulb temperature (DBT) and wetbulb (WB) depression for Kuda wood at $50-70{ }^{\circ} \mathrm{C}$ and $3-30^{\circ} \mathrm{C}$; Waru wood at $65-80^{\circ} \mathrm{C}$ and $6-30^{\circ} \mathrm{C}$; and Mindi besar wood at $55-80^{\circ} \mathrm{C}$ and $4-$ $30^{\circ} \mathrm{C}$. However, those drying schedules need to be modified during its implementation and adjusted to kiln drying condition, initial moisture content and the dimension

4. There is a close relationship between wood properties and its drying properties.

\section{REFFERENCES}

Anonim. 1995. Standard methods of testing small clear specimens of timber. In Annual Book of ASTM Standard vol. 4, sec.4. Construction. Philadelphia. 
Basri, E. and N. Hadjib. 2003. The relation between basic properties and drying properties of five priority wood species from West Java. Journal of Forest Products Research 22 (3): 155-166 Center for Forest Products Technology Research and Development. Bogor (In Indonesia with English summary).

Departemen Kehutanan. 2003. Rencana Strategi Departemen Kehutanan 2001-2005 (Penyempurnaan). Pusat Informasi Kehutanan. Jakarta.

Mandang, Y.I. dan S. Artistien. 2003. Wood anatomy and fibre quality of utap-utap and seven other lesser known wood species. Forest Products Reasearsch Bulletin 21 (2): 111-127. Center for Forest Products Technology Research and Development. Bogor (In Indonesia with English summary).

Ministry of Agriculture. 1976. Vademecum of Indonesian Forestry. DG. of Forestry - Ministry of Agriculture, Jakarta.

Oey, D. S. 1990. Berat Jenis Kayu-kayu Indonesia dan Pengertian dari Berat Kayu Untuk Keperluan Praktek. Pengumuman No. 11. Lembaga Penelitian Hasil Hutan. Bogor. Cetak ulang

Panshin A.J. and C. de Zeeuw.1969. Text Book of Wood Technology, $3^{\text {rd }}$ edition. McGraw-Hill Book Co., pp.150-197. New York.

Rachman, O. 2002. Machining and sawing properties of five priority wood species from West Java. Research Report. Center for Forest Products Technology Research and Development. Bogor (in Indonesia, Unpublished).

Rasmussen, E.F. 1961. Dry Kiln Operator's Manual. U.S. Department of Agriculture. Agric. Handbook 188.

Senft, J.F., B.A. Bentsen and W.L. Galligan. 1986. Weak wood, fast grown trees make problem lumber. Journal of Forestry.

Skaar, C. 1988. Wood-water relations, Springer-Verlag, Berlin.

Terazawa, S. 1965. An easy methods for the determination of wood drying schedule. Wood Industry 20 (5), Wood Technological Association of Japan.

Wahyudi, I. 2000. Studies on the growth and wood qualities of tropical plantation species. Dissertation for the degree of Doctor of Phylosophy in Wood Physics. The Graduate School of Bioagricultural Sciences, Nagoya University. Japan. Unpublished. 